\title{
NEUROTRANSMITTER- AND NEUROMODULATOR-DEPENDENT ALTERATIONS IN PHOSPHORYLATION OF PROTEIN I IN SLICES OF RAT FACIAL NUCLEUS ${ }^{1}$
}

\author{
ANNETTE C. DOLPHIN"2 AND PAUL GREENGARD 3 \\ Department of Pharmacology, Yale University School of Medicine, New Haven, Connecticut 06510
}

\begin{abstract}
Protein I is a neuronal phosphoprotein associated primarily with synaptic vesicles. Regulation of its state of phosphorylation has been investigated in slices of rat facial nucleus. This brainstem motor nucleus has a facilitatory serotonergic input and contains no interneurons. Serotonin (5-hydroxytryptamine, 5-HT, 10 $\mathbf{M})$, in the presence of the phosphodiesterase inhibitor isobutylmethylxanthine (IBMX, $4 \times 10^{-5.5} \mathbf{M}$ ), converted approximately 26\% of Protein I in these slices from the dephospho-form to the phospho-form. This effect was partially inhibited using two classical 5-HT antagonists, mianserin added to the slices during in vitro incubation and metergoline administered in vivo. The effect of $5-\mathrm{H}^{\prime} \mathrm{T}$ appeared to be $\mathrm{Ca}^{2+}$ dependent, unlike that of IBMX $\left(10^{-3} \mathbf{M}\right)$.

Adenosine, its analog 2-chloroadenosine, and ATP also increased the phosphorylation of Protein I in facial nucleus slices. 2-Chloroadenosine $\left(5 \times 10^{-4} \mathrm{M}\right)$ caused a $29 \%$ phosphorylation of Protein I, and this effect was not dependent on extracellular $\mathrm{Ca}^{2+}$. The phosphorylation of Protein I caused both by 2chloroadenosine and by ATP was inhibited by the adenosine antagonist 2 '-deoxyadenosine.

Results of additional experiments suggest that the great majority of the Protein $I$ in the facial nucleus is present in presynaptic terminals other than the serotonergic afferents. It is concluded that the stimulation by 5-HT and adenosine of Protein I phosphorylation results largely from a direct action of these compounds on those Protein I-containing terminals.
\end{abstract}

Many agents raise intracellular cyclic AMP levels of nervous tissue by acting on membrane receptors (for reviews, see Bloom, 1975; Daly, 1976; Nathanson, 1977; Greengard, 1979). In the brain, this has been proposed as a mechanism of action for several putative neurotransmitters and neuromodulators. These include norepinephrine acting on $\beta$-adrenergic receptors (Kakiuchi and Rall, 1968; Daly, 1976; Bockaert et al., 1977; Dolphin et al., 1979), dopamine acting on $D_{1}$ receptors (Kebabian et al., 1972; Kebabian and Calne, 1979), adenosine (Sattin and Rall, 1970; Prémont et al., 1977), serotonin (5-hydroxytryptamine, 5-HT) (Kakiuchi and Rall, 1968; Enjalbert

\footnotetext{
1 This work was supported in part by a fellowship from the Coxe Alexander B. Memorial Fund (A. C. D.), United States Public Health Service Research Grants DA-06127, MH-17387, AA-04183, and NS08440 (P. G.), and a grant from the McKnight Foundation and from Hoffmann La Roche (P. G.). We would like to thank Frank Wilson for preparing the catalytic subunit of cyclic AMP-dependent protein kinase and Dr. George K. Aghajanian for much valuable advice and for provision of histological facilities.

${ }^{2}$ Present address: Division of Neurophysiology and Neuropharmacology, National Institute of Medical Research, Mill Hill, London NW7 1AA, United Kingdom.

${ }^{3}$ To whom reprint requests should be addressed at Department of Pharmacology, Yale University School of Medicine, P. O. Box 3333, 333 Cedar Street, New Haven, CT 06510.
}

et al., 1978), and histamine (Hegstrand et al., 1976). The only known intracellular effect of cyclic AMP in higher organisms is to activate cyclic AMP-dependent protein kinases (Walsh et al., 1968; Kuo and Greengard, 1969; Greengard, 1979), which phosphorylate specific substrate proteins (for reviews, see Krebs and Beavo, 1979; Greengard, 1980). It has been difficult, however, to demonstrate that the stimulation of intact neuronal tissue by neurotransmitters or neuromodulators affects the phosphorylation of any specific substrate protein. The present study concerns the regulation of phosphorylation of one of these substrates, Protein I, a synapse-specific neuronal phosphoprotein (for review, see Greengard, 1980).

Protein I is present throughout the central (Bloom et al., 1979; De Camilli et al., 1980) and peripheral (De Camilli et al., 1979) nervous systems. Immunocytochemical and subcellular fractionation studies (Bloom et al., 1979; Ueda et al., 1979; De Camilli et al., 1979; W. B. Huttner, P. De Camilli, S. E. Goelz, and P. Greengard, unpublished results) indicate that Protein $I$ is present primarily in neuronal terminals and, within these terminals, is associated with synaptic vesicles. It occurs as two subspecies, Proteins Ia and Ib, of molecular weights 86,000 and 80,000 , which possess very similar properties (Ueda and Greengard, 1977). In cell-free preparations from brain, Protein I is a substrate for both cyclic AMP- 
dependent (Ueda et al., 1973) and $\mathrm{Ca}^{2+}$-dependent (Krueger et al., 1977) protein kinases, and these show differential specificity for the multiple phosphorylation sites on Protein I (Huttner and Greengard, 1979).

In slices of rat cerebral cortex, Protein I was phosphorylated by agents such as isobutylmethylxanthine (IBMX), a phosphodiesterase inhibitor which increases intracellular cyclic AMP levels, and by the cyclic AMP analog, 8-bromo-cyclic AMP (Forn and Greengard, 1978). The phosphorylation of Protein I was also stimulated by agents such as veratridine and elevated extracellular $\mathrm{K}^{+}$ which caused $\mathrm{Ca}^{2+}$ influx. However, none of the many putative neurotransmitters tested in that study had any detectable effect on the state of phosphorylation of Protein $I$ in the slices, despite the known ability of some of the substances tested, including norepinephrine and adenosine, to elevate cyclic AMP levels in slices of rat cerebral cortex (Huang et al., 1973b; Perkins and Moore, 1973). The apparent refractoriness of Protein I phosphorylation in cerebral cortex slices to regulation by neurotransmitters may be attributable to the complexity of this tissue in terms both of the many types of neurotransmitters present and of the diversity of responses produced by any given neurotransmitter acting on various classes of pre- and postsynaptic neuronal elements.

To circumvent this problem, we have, in the present investigation, utilized a tissue slice preparation from a better defined region of the central nervous system in the rat, the facial motor nucleus. This brainstem nucleus contains a single class of neuronal cell bodies and no interneurons (Courville, 1965; McCall and Aghajanian, 1979a). The majority of the afferent fibers to the facial nucleus are excitatory onto the facial motor neurons, and the effect of stimulation of these afferents on motoneuron firing is mimicked by the iontophoresis of glutamate (McCall and Aghajanian, 1979a). The facial nucleus also receives a minor serotonergic input from the nucleus raphé magnus (Dahlstrom and Fuxe, 1965; Palkovits et al., 1974; McCall and Aghajanian, 1979a), and iontophoresis of either $5-\mathrm{HT}$ or the $5-\mathrm{H}$ T releasing agent, $p$ chloroamphetamine, has been shown to facilitate the stimulation of motoneuron firing by glutamate (McCall and Aghajanian, 1979a, 1980). Thus, the rationale behind using this brain region for studies of Protein I phosphorylation is that the great majority of nerve terminals in the facial nucleus appear to be of a single type. If the phosphorylation of Protein $I$ in this region were sensitive to neurotransmitters or neuromodulatory agents which altered cyclic AMP or $\mathrm{Ca}^{2+}$ levels within these terminals, then a large proportion of the total Protein I within the facial nucleus might be capable of responding to any given agent in a similar manner. Preliminary reports of the stimulation of Protein I phosphorylation by 5 - HT have already been made (Greengard, 1980; Dulphin and Greengard, 1981).

In studies of the peripheral nervous system, it has since been found that dopamine increases the state of phosphorylation of Protein I in slices of bovine superior cervical ganglion (Nestler and Greengard, 1980). This finding adds support to the view that the state of phosphorylation of Protein I can be influenced by neurotransmitters and neuromodulators in nervous tissue.

\section{Materials and Methods}

Tissue preparation. Male Sprague-Dawley rats (150 to $200 \mathrm{gm}$ ) were killed by decapitation. The brain was removed, and the brainstem was dissected out and placed on its dorsal surface. A transverse slice, $1.2 \mathrm{~mm}$ thick, was taken through the brainstem at the posterior edge of the trapezoid body (between 3.8 and $5.0 \mathrm{~mm}$, posterior to the interauricular line, according to the atlas of Palkovits and Jacobowitz (1974)). The two facial nuclei were dissected manually from this slice as cuboids taken from the ventral edge of the slice with the lateral edges of the pyramidal tracts as the medial borders.

For experiments in which total Protein I levels were determined, each excised facial nucleus was homogenized in $1 \mathrm{ml}$ of $10 \mathrm{~mm}$ HEPES (4-(2-hydroxyethyl)-1-piperazineethanesulfonic acid), $\mathrm{pH} 7.4$, containing 2 mM EGTA (ethylene glycol bis ( $\beta$-aminoethyl ether)- $N, N, N^{\prime}, N^{\prime}$-tetraacetic acid) and 50 units $/ \mathrm{ml}$ of the protease inhibitor Trasylol, in a Teflon-glass homogenizer. Samples were either diluted into $5 \mathrm{~mm}$ zinc acetate and rehomogenized for assay of total Protein I by phosphorylation or aliquots were boiled in the presence of $1 \%$ sodium dodecyl sulfate (SDS) and the samples were stored at $-20^{\circ} \mathrm{C}$ until analyzed for Protein I by radioimmunoassay (S. E. Goelz, unpublished methodology).

For the tissue slice incubation experiments, each excised facial nucleus was quartered using a sagittal and a horizontal cut. The four slices thus prepared from a single facial nucleus were transferred together to a glass homogenizer containing $10 \mathrm{ml}$ of Krebs-Ringer bicarbonate buffer (KRB), pH 7.4 at $35^{\circ} \mathrm{C}$ (composition in millimolar concentrations: $\mathrm{Na}^{+}, 158 ; \mathrm{K}^{+}, 3 ; \mathrm{Ca}^{2+}, 1.5 ; \mathrm{Mg}^{2+}, 1.3$; $\mathrm{PO}_{4}^{3-}, 1.3 ; \mathrm{HCO}_{3}^{-}, 25 ; \mathrm{Cl}^{-}, 136$; ascorbate, I; D-glucose, 20). In experiments in which $\mathrm{Ca}^{2+}$-free medium was used, $\mathrm{Ca}^{2+}$ was replaced isotonically by $\mathrm{Na}^{+}$and EGTA was added to a final concentration of $0.3 \mathrm{~mm}$. The medium was gassed continuously with $\mathrm{H}_{2} \mathrm{O}$-saturated $95 \% \mathrm{O} .2,5 \%$ $\mathrm{CO}_{2}$ throughout the preincubation and incubation periods.

Slices were preincubated for $1 \mathrm{hr}$ with one change of medium, except in experiments in which the effect of $\mathrm{Ca}^{2+}$-free medium was tested; in these experiments, both control and test slices were preincubated for $1 \mathrm{hr}$ with three changes of medium. In all cases, the effect of the agent to be tested was determined on one of a pair of facial nuclei, the other of which was used as a control. With the exception of metergoline, all agents were dissolved in $\mathrm{KRB}$, with or without $\mathrm{Ca}^{2+}$ as appropriate, and the $\mathrm{pH}$ was adjusted to 5.5 to 7.5 using phenol red as an indicator. Metergoline was dissolved in a small volume of $2.5 \%$ ascorbic acid before dilution in KRB and was used immediately because of its instability; in these experiments, control incubation vessels received the same vehicle. Incubations were begun by addition of the test substance or vehicle in KRB. The final incubation volume was $10 \mathrm{ml}$. Incubations were terminated by aspirating the KRB and homogenizing the slices in $5 \mathrm{ml}$ of ice cold zinc acetate $(5 \mathrm{~mm})$. This procedure arrests phosphatase activity (Forn and Greengard, 1978).

Extraction and assay of Protein 1. All steps of the extraction procedure were performed at $4^{\circ} \mathrm{C}$. The zinc 
acetate homogenate was centrifuged at $4000 \times g$ for 15 min, and the pellet was resuspended in $1 \mathrm{ml}$ of $10 \mathrm{~mm}$ sodium citrate/phosphate buffer, $\mathrm{pH} 2.8$ at $4{ }^{\circ} \mathrm{C}$. Duplicate or triplicate aliquots of this suspension were taken for protein assay by either the method of Lowry et al. (1951) or a method with which monoamines did not interfere (Bradford, 1976). The results using the two methods were equivalent. Unless otherwise stated, Protein I levels, expressed as phosphate incorporated per milligram of protein, have been calculated from this value, which is zinc acetate-precipitable protein rather than total protein. The suspension was centrifuged at $23,000 \times g$ for $15 \mathrm{~min}$, and $500 \mu \mathrm{l}$ of the supernatant was adjusted to $\mathrm{pH} 6$ with $0.5 \mathrm{M} \mathrm{Na}_{2} \mathrm{HPO}_{4}$ and centrifuged at $15,000 \times g$ for $15 \mathrm{~min}$. The $\mathrm{pH} 6$ supernatants in each experiment then were diluted to equal protein concentration with $10 \mathrm{~mm}$ sodium citrate/phosphate buffer $(\mathrm{pH} 6)$. Duplicate or triplicate $60-\mu \mathrm{l}$ aliquots of these neutralized acid extracts were used in a phosphorylation assay containing (in $100 \mu \mathrm{l}$, final volume): $50 \mathrm{~mm} \mathrm{HEPES}$ (pH 7.4), $10 \mathrm{~mm} \mathrm{Mg}^{2+}$, $1 \mathrm{~mm}$ EGTA, $1 \mathrm{~mm}$ EDTA (ethylenediaminetetraacetate), $3 \mu \mathrm{M}\left[\gamma^{3}{ }^{32} \mathrm{P}\right] \mathrm{ATP}$ (specific activity, 50 to $100 \mathrm{cpm} / \mathrm{fmol}$ ), and $7.5 \mathrm{~nm}$ of the catalytic subunit (C) of cyclic AMP-dependent protein kinase, purified according to the method of Beavo et al. (1974). The samples were incubated for $30 \mathrm{~min}$ at $30^{\circ} \mathrm{C}$, and the reaction was stopped by the addition of $50 \mu \mathrm{l}$ of a "stop" solution containing $9 \%$ SDS, $6 \% \beta$-mercaptoethanol, $15 \%$ glycerol, and $0.01 \%$ bromphenol blue dye in $186 \mathrm{~mm}$ Tris. $\mathrm{HCl}(\mathrm{pH}$ 6.7). The incubation conditions used resulted in maximal phosphorylation of tryptic phosphopeptide 1 of Protein I; none of the other phosphorylation sites on Protein I were phosphorylated using this low concentration of $\mathrm{C}$ (Huttner and Greengard, 1979; A. C. Dolphin, unpublished results). The samples were then immediately subjected to SDS-polyacrylamide gel electrophoresis as previously described (Liu and Greengard, 1976) except that the final acrylamide concentration of the separating gel was $8 \%$. The gels were washed briefly in hot water, dried without fixing and subjected to autoradiography. The amount of phosphate incorporated into Protein I in each sample was determined by cutting out the dried gel piece containing the Protein Ia and Ib bands together and determining the amount of ${ }^{32} \mathrm{P}$ incorporated into these bands by liquid scintillation spectrometry.

A sample $(100 \mu \mathrm{l})$ of each neutralized acid extract was mixed directly with $50 \mu$ l of the same "stop" solution and subjected to SDS-polyacrylamide gel electrophoresis, and the gels were stained for protein using Coomassie blue $\mathrm{R}$, destained, and dried as previously described (Ueda et al., 1973). The protein stained gels were used as a qualitative check that all the neutralized acid extracts contained similar amounts and patterns of protein.

Calculation of Protein I phosphorylation. In most experiments, each pair of facial nuclei was incubated so that one served as a control for the effect of an agent on the other. This protocol was adopted in order to reduce the effect of variability between animals.

Except for the data presented in Table I, the percentage of conversion of dephospho-Protein I to phosphoProtein I caused by any agent was calculated for each pair of incubations according to the formula

$$
100 \times\left(P_{0}-P\right) / P_{0}
$$

where $P_{0}$ is the amount of phosphate incorporated into Protein I per milligram of protein in the extract of the control facial nucleus, and $P$ is the amount of phosphate incorporated into Protein I per milligram of protein in the extract of the experimental facial nucleus. Each data point represents the mean \pm SEM of the number of pairs of samples indicated.

Peptide mapping after limited proteolysis of Protein $I$ using Staphylococcus aureus V8 protease (SAP). Protein I phosphorylated with $\left[\gamma-{ }^{32} \mathrm{P}\right] \mathrm{ATP}$, under the standard assay conditions described above was subjected to peptide mapping after limited proteolysis according to the method of Cleveland et al. (1977), incorporating the modifications previously described (Huttner and Greengard, 1979). This procedure resulted in the generation of a single ${ }^{32} \mathrm{P}$-labeled $M_{r}=10,000$ fragment. This fragment has been shown (Huttner et al., 1981) to contain only tryptic phosphopeptide 1 and none of the other tryptic phosphopeptides identified by Huttner and Greengard (1979) and Huttner et al. (1981).

Preparation of lesioned animals. Intraventricular infusion of 5,7-dihydroxytryptamine (5,7-DHT) was performed as previously described (McCall and Aghajanian,

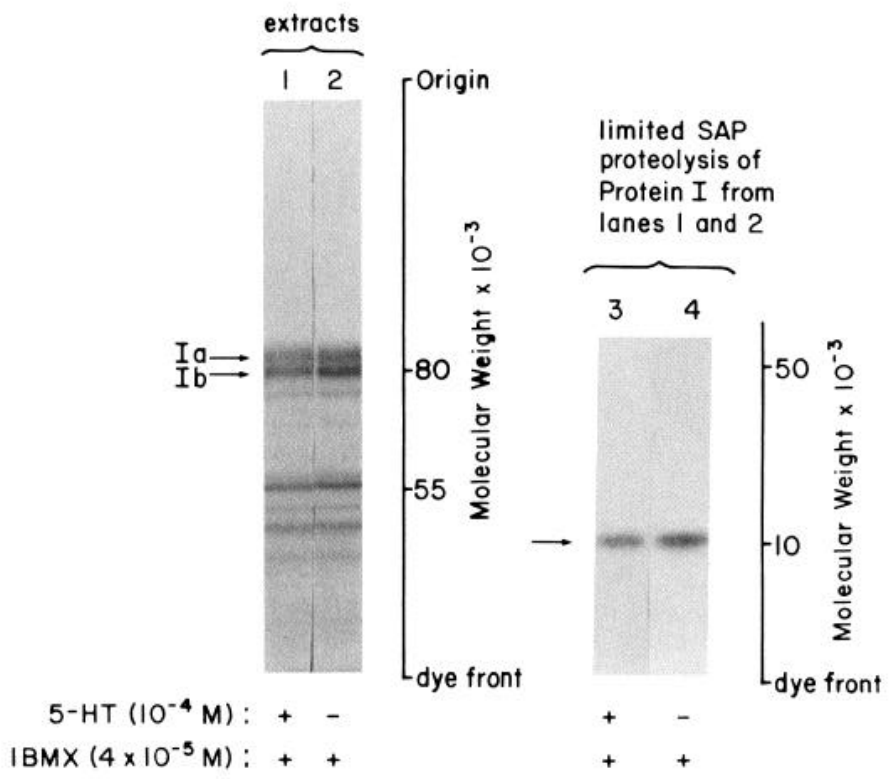

Figure 1. Effect of 5-HT $\left(10^{-4} \mathrm{M}\right)$ in the presence of IBMX $\left(4 \times 10^{-5} \mathrm{M}\right)$ on the state of phosphorylation of Protein I in slices of rat facial nucleus incubated in KRB containing $1.5 \mathrm{~mm}$ $\mathrm{Ca}^{2+}$. The first two lanes are autoradiographs of neutralized acid extracts prepared from slices of facial nuclei incubated in the presence (lane 1) and absence (lane 2) of 5-HT $\left(10^{-4} \mathrm{M}\right)$ and phosphorylated with $\left[\gamma-{ }^{32} \mathrm{P}\right] \mathrm{ATP}$ as described under "Materials and Methods." The proteins were separated by SDSpolyacrylamide gel electrophoresis using an $8 \%$ running gel. Proteins Ia and Ib are indicated by arrows. Lanes 3 and 4 show the single phosphopeptide $\left(M_{r}=10,000\right.$, indicated by an arrow) derived from Protein I in lanes 1 and 2, respectively; the Protein Ia and Ib bands were cut out from the gels and digested with SAP as described previously (Cleveland et al., 1977; Huttner and Greengard, 1979), and the proteolytic fragments were separated by SDS-polyacrylamide gel electrophoresis using a $15 \%$ running gel. The stimulation of phosphorylation of Protein I in the slices due to 5 -HT was $28.0 \%$ in this experiment, and a similar stimulation $(30.1 \%)$ was obtained in the $M_{r}=10,000$ phosphopeptide. 


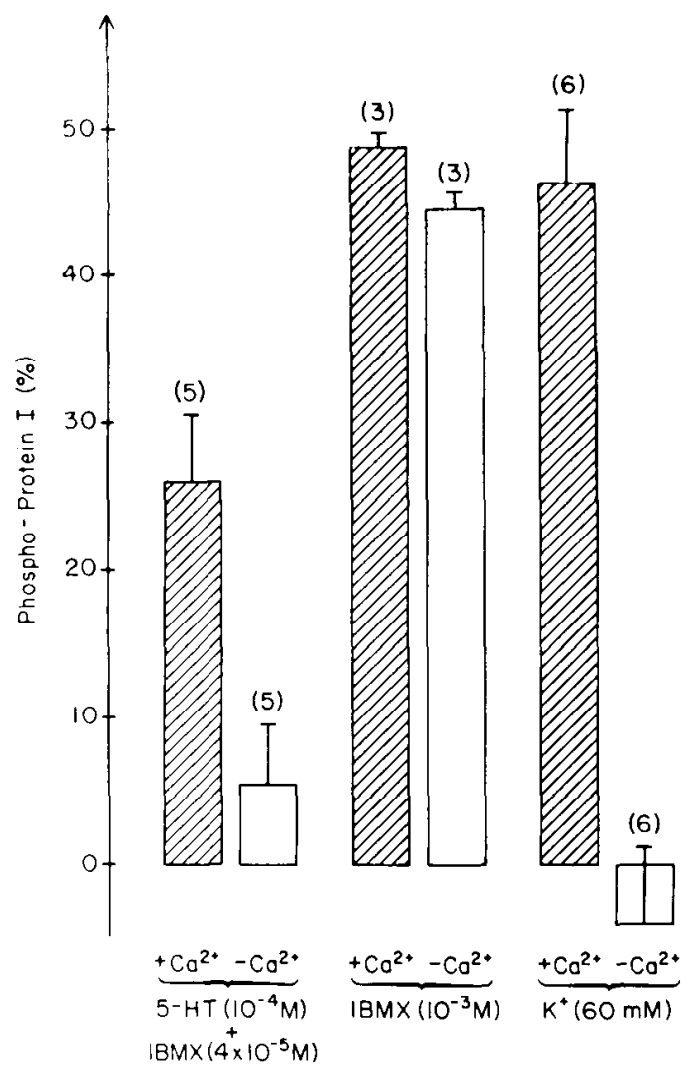

Figure 2. Stimulation of phosphorylation of Protein I by 5 $\mathrm{H}^{\prime} \mathrm{T}$, IBMX, and $\mathrm{K}^{*}$ slices of rat facial nucleus and its dependence on extracellular $\mathrm{Ca}^{2+}$. One member of each pair of facial nuclei was incubated with, and one without, 5-HT, IBMX, or $\mathrm{K}^{+}$as indicated. Both members of each pair of facial nuclei were incubated either with $1.5 \mathrm{~mm} \mathrm{Ca}{ }^{2+}-\mathrm{KRB}$ (shaded bars) or with $\mathrm{Ca}^{2+}$-free, $0.3 \mathrm{~mm}$ EGTA-KRB (open bars). The incubation in $60 \mathrm{~mm} \mathrm{~K}{ }^{+}$was for $1 \mathrm{~min}$, and the incubations with IBMX $\left(10^{3 \mathrm{M}}\right)$ and 5 -HT $\left(10^{-4} \mathrm{M}\right)$ were for $10 \mathrm{~min}$. IBMX (4 $\times 10^{\circ}$ M) was added 2 min before 5 -HT or 12 min before the end of the incubation in the paired control slices. The percentage of conversion of dephospho- to phospho-Protein I, caused by the addition of the stimulatory agent to one of each pair of facial nuclei, was determined as described under "Materials and Methods." Results are the means \pm SEM for the number of pairs of incubations given in parentheses.

1979b). Rats were anesthetized with chloral hydrate ( 350 $\mathrm{mg} / \mathrm{kg}$, i.p.) and pretreated for $30 \mathrm{~min}$ with desmethylimipramine- $\mathrm{HCl}(25 \mathrm{mg} / \mathrm{kg}$, i.p.) to reduce uptake of $5,7-$ DHT into noradrenergic terminals. Four hundred micrograms of 5,7-DHT creatinine sulfate was dissolved in 10 $\mu \mathrm{l}$ of $0.1 \%$ sodium ascorbate in phosphate-buffered saline $(0.9 \% \mathrm{NaCl}$ in $10 \mathrm{~mm}$ sodium phosphate, $\mathrm{pH} \mathrm{7.4)}$ and stereotaxically infused over a period of 10 min into the left lateral ventricle. Control animals were prepared in parallel by infusion of $10 \mu \mathrm{l}$ of vehicle.

Kainic acid lesions were performed stereotaxically using rats weighing 300 to $350 \mathrm{gm}$ and anesthetized with chloral hydrate $(400 \mathrm{mg} / \mathrm{kg}$, i.p.). Kainic acid was dissolved in $0.1 \%$ sodium ascorbate in phosphate-buffered saline and infused into the left facial nucleus (coordinates $2.3 \mathrm{~mm}$ posterior to lambda, $1.9 \mathrm{~mm}$ lateral to the midline, and $7.9 \mathrm{~mm}$ ventral to the surface of the cerebellum). The rate of infusion was $0.025 \mu \mathrm{l} / \mathrm{min}$ and a total of 0.1 $\mu \mathrm{g}$ of kainic acid was infused in $20 \mathrm{~min}$. The needle was then left in place for $10 \mathrm{~min}$ before retraction. Control animals were prepared in parallel by infusion of $0.5 \mu \mathrm{l}$ of vehicle into the left facial nucleus.

Materials. Drugs and biochemicals were obtained from the following sources: 5 -hydroxytryptamine creatinine sulfate, kainic acid, 2-chloroadenosine, adenine, ATP (equine muscle), adenylyl imidodiphosphate (AMPPNP), and 2'-deoxyadenosine from Sigma; metergoline free base from Farmitalia; mianserin from Astra; isobutylmethylxanthine from Aldrich; fluphenazine from Smith, Kline \& French; 5-methoxy- $N, N^{\prime}$-dimethyltryptamine (5-MeO-DMT) and 5,7-dihydroxytryptamine from Regis Chemical Co.; desmethylimipramine- $\mathrm{HCl}$ from Richardson-Merrell, Inc.; 2'-deoxy-ATP from Schwarz/ Mann; cyproheptadine from Merck, Sharpe \& Dohme; adenosine from Boehringer, Mannheim; Trasylol from Mobay Chemical Corp.; and Staphylococcus aureus V8 protease from Miles, U. K.

\section{Results \\ 5-HT-dependent phosphorylation of Protein I in facial
nucleus slices}

Effect of 5-HT on Protein I phosphorylation. Serotonin $\left(10^{-1} \mathrm{M}\right)$, in the presence of a low concentration of IBMX $\left(4 \times 10^{-5} \mathrm{M}\right)$ which alone had little effect on Protein I phosphorylation, stimulated the phosphorylation of Protein I when incubated for 10 min with slices of rat facial nucleus. This effect can be seen in both the Protein I band itself (Fig. 1, lane 1 versus 2) and the $M$, $=10,000$ phosphorylated fragment that is obtained from Protein I after digestion with SAP (Fig. 1, lane 3 versus 4). The phosphorylation of several other phosphoproteins in the neutralized acid extract was also stimulated by 5 HT. Since the "back phosphorylation" assay was performed using a low concentration of $C$, proteins which are good substrates for cyclic AMP-dependent protein kinase and whose state of phosphorylation is likely to be affected in intact systems by agents which alter intracellular cyclic AMP levels were selectively phosphorylated.

Effect of $\mathrm{Ca}^{2+}$-free medium on 5-HT stimulation of Protein I phosphorylation. The effect of removing $\mathrm{Ca}^{2+}$ from the preincubation and incubation medium on stimulation of Protein I phosphorylation by 5-HT $\left(10^{-4} \mathrm{M}\right)$, $\operatorname{IBMX}\left(10^{-3} \mathrm{M}\right)$, and $\mathrm{K}^{+}(60 \mathrm{mM})$ is shown in Figure 2. 5HT $\left(10^{-4} \mathrm{M}\right)$ produced a $26 \%$ phosphorylation of Protein I in the presence of $\mathrm{Ca}^{2+}$; this effect was markedly reduced in the absence of $\mathrm{Ca}^{2+}$. IBMX $\left(10^{-3.3} \mathrm{M}\right)$ produced a 48\% phosphorylation of Protein I in the presence of $\mathrm{Ca}^{2+}$ and a similar phosphorylation in the absence of $\mathrm{Ca}^{2+}$. Incubation of slices for $1 \mathrm{~min}$ with $60 \mathrm{~mm} \mathrm{~K} \mathrm{~K}^{+}$ produced a $42 \%$ phosphorylation of Protein I in the presence of $\mathrm{Ca}^{2+}$; this effect was abolished in the absence of $\mathrm{Ca}^{2+}$.

In this series of experiments, the basal amount of back phosphorylation of Protein I by $\left[\gamma^{-32} \mathrm{P}\right] \mathrm{A} T \mathrm{TP}$ was $7.1 \pm 0.6$ $\mathrm{pmol} / \mathrm{mg}$ of protein $(n=14)$ in the presence of $\mathrm{Ca}^{2+}$ and $10.0 \pm 0.8 \mathrm{pmol} / \mathrm{mg}$ of protein $(n=14)$ in the absence of $\mathrm{Ca}^{2+}$. Thus, even under basal conditions, added $\mathrm{Ca}^{2+}$ in the incubation medium appeared to stimulate Protein I phosphorylation in the intact slices.

The effect of several 5-HT agonists and antagonists on Protein I phosphorylation. Several agents were in- 
vestigated both for their ability to alter the basal state of phosphorylation of Protein I and for their effect on 5HT-induced Protein I phosphorylation in rat facial nucleus slices. The results are shown in Table I. The 5-HT receptor agonist, 5-methoxydimethyltryptamine (5MeO-DMT, $2 \times 10^{-4} \mathrm{M}$ ), slightly stimulated the phosphorylation of Protein I and reduced the stimulation due to 5-HT $\left(10^{-4} \mathrm{M}\right)$. The 5-HT antagonist, mianserin $\left(10^{-5}\right.$ M), had a similar effect alone and significantly inhibited the phosphorylation of Protein I due to 5-HT. The phosphorylation of Protein I caused by mianserin $\left(10^{-5} \mathbf{M}\right)$ alone was also observed at other concentrations of mianserin, being $8.1 \%$ at $10^{-6} \mathrm{M}$ and $12.8 \%$ at $10^{-4} \mathrm{M}$ mianserin $(n=2)$. Cyproheptadine $\left(10^{-5} \mathrm{M}\right)$, a related 5 -HT antagonist (Vargaftig et al., 1971), caused a $22.9 \%$ phosphorylation of Protein I $(n=3)$. In the presence of cyproheptadine, no further stimulation of phosphorylation was produced by $5-\mathrm{HT}$. Although another 5-HT antagonist, metergoline $\left(10^{-5} \mathrm{M}\right)$, produced a slight phosphorylation of Protein I alone, it did not inhibit the phosphorylation caused by 5 -HT $\left(10^{-4} \mathrm{M}\right)$. However, when metergoline was administered in vivo at a dose of $1 \mathrm{mg} / \mathrm{kg}$, i.p., $1 \mathrm{hr}$ prior to death, the stimulation of Protein I phosphorylation due to 5-HT $\left(10^{-4} \mathrm{M}\right)$ in slices of facial nucleus prepared from these animals was $16.4 \pm 4.2 \%(n=6)$ compared to $24.5 \pm 3.5 \%(n=4)$ in control rats. A dopamine receptor antagonist, fluphenazine $\left(10^{-5} \mathrm{M}\right)$, had no effect in vitro either on basal or on 5 -HT-stimulated Protein I phosphorylation.

Incubation of facial nucleus slices with $p$-chlorophenylethylamine $\left(5 \times 10^{4} \mathrm{M}\right)$ for $10 \mathrm{~min}$ in the presence of IBMX $\left(4 \times 10^{-5} \mathrm{M}\right)$ resulted in a small $(11.2 \pm 2.4 \%, n=$ 4) increase in Protein I phosphorylation compared to control slices incubated with IBMX $\left(4 \times 10^{-5} \mathrm{M}\right)$ alone. This compound produces a rapid and specific release of 5-HT (Hwang and Van Woert, 1979). In other experiments, pretreatment of rats for $18 \mathrm{hr}$ with $p$-chlorophenylalanine (PCPA-methyl ester; $400 \mathrm{mg} / \mathrm{kg}$, i.p.), which is a 5-HT-depleting agent (Koe and Weissman, 1966), did not alter the response to $10^{-4} \mathrm{M}$ 5-HT in slices of facial nucleus subsequently prepared from these rats; 5 -HT $\left(10^{-4} \mathrm{M}\right)$ in the presence of IBMX $\left(4 \times 10^{-5} \mathrm{M}\right)$ produced a $25.1 \%$ phosphorylation of Protein $I$ in control rats and a $28.2 \%$ phosphorylation of Protein I in PCPA-treated animals $(n=2)$.

\section{Adenosine-dependent phosphorylation of Protein I in facial nucleus slices}

Effect of various adenosine analogs on Protein I phosphorylation. The ability of adenosine and various related compounds to stimulate the phosphorylation of Protein I when incubated for $10 \mathrm{~min}$ at a concentration of $5 \times 10^{-4} \mathrm{M}$ with facial nucleus slices is shown in Figure 3. ATP, 2-chloroadenosine, and adenosine all produced a significant phosphorylation of Protein I, whereas 2 '.

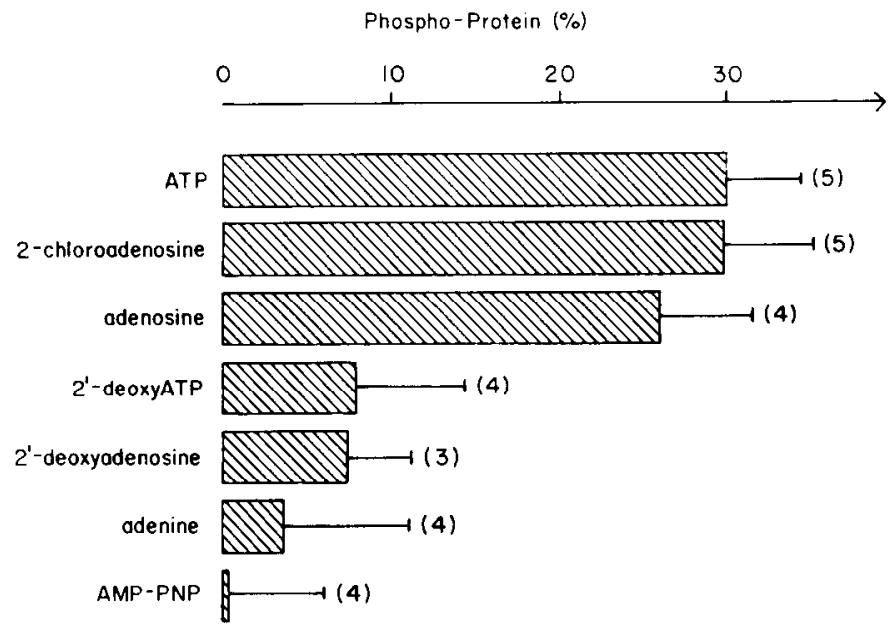

Figure 3. Effect of adenosine and related compounds on the conversion of dephospho- to phospho-Protein I in slices of rat facial nucleus incubated in vitro. All incubations were carried out in $\mathrm{KKB}$ containing $1.5 \mathrm{mM} \mathrm{Ca}^{2+}$, and all agents were added at a concentration of $5 \times 10^{-4} \mathrm{M}$ to one of a pair of facial nuclei; the other of which served as a control. The results are the means \pm SEM for the number of pairs of incubations given in parentheses. The stimulation of Protein I phosphorylation due to ATP, 2-chloroadenosine, and adenosine was statistically significant $(p<0.01$, Student's $t$ test) when compared to respective controls.

TABLE I

Effect of various test substances on 5-HT-stimulated Protein I phosphorylation

One of each pair of facial nucleus slices was incubated with, and one without, 5 -HT $\left(10^{-4} \mathrm{M}\right)$ for $10 \mathrm{~min}$. When the substances to be tested were included, they were added to both members of the pair at the final concentration indicated 15 min before the end of the incubation. IBMX (4 $\times$ $10^{-5} \mathrm{M}$ ) was present in all incubation tubes and was added $12 \mathrm{~min}$ before the end of the incubation. The percentage of conversion of dephosphoProtein I to phospho-Protein I was calculated with reference to slices incubated under basal conditions (no 5-HT; no test substance) in each experiment. The increase in phospho-Protein $\mathrm{I}$, in picomoles per milligram of protein, due to 5 -HT was calculated directly for each pair of facial nucleus slices; the means \pm SEM are given for each experimental condition.

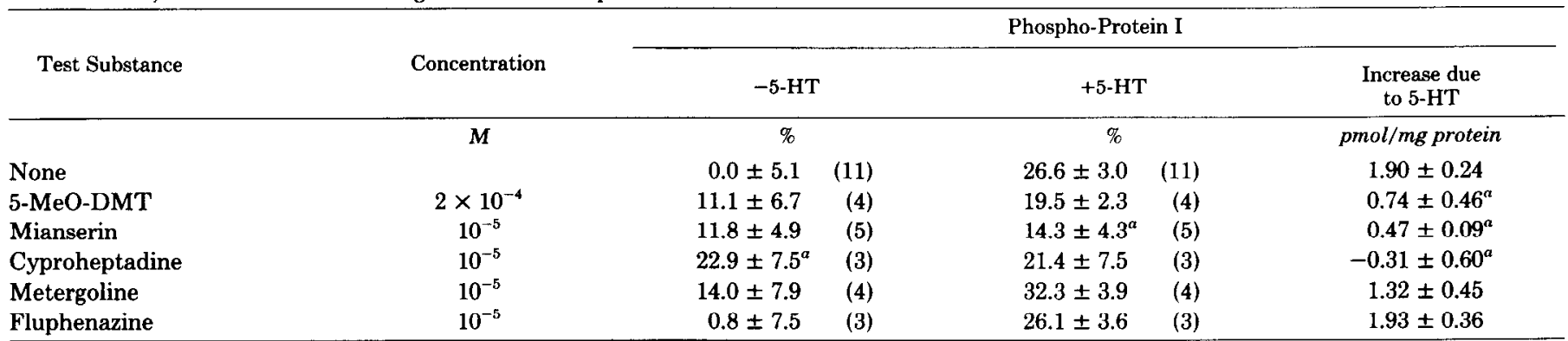

${ }^{a} p<0.05$, compared to no test substance, for each column (Student's $t$ test). 
deoxy-ATP, 2 -deoxyadenosine, adenine, and AMP-PNP (an ATPase-resistant analog of ATP) did not.

To determine whether the effect of ATP could be accounted for by the presence of residual ATP carried over from the incubation medium to the final neutralized acid extract and consequent dilution of the specific activity of the $\left[\gamma^{32} \mathrm{P}\right] \mathrm{ATP}$ used in the phosphorylation assay, $0.1 \mu \mathrm{mol}$ of ATP was added to the zinc acetate homogenate of one of a pair of facial nuclei, both of which had been incubated under basal conditions. The basal level of back phosphorylation of Protein I by $\left[\gamma^{32} \mathrm{P}\right] \mathrm{ATP}$ was $7.6 \pm 0.5 \mathrm{pmol}$ of phosphate $/ \mathrm{mg}$ of protein $(n=4)$ in the facial nuclei whose extraction was performed in the presence of $0.1 \mu \mathrm{mol}$ of ATP added in vitro and was not altered in the paired controls, being $6.8 \pm 0.2 \mathrm{pmol}$ of phosphate/mg of protein $(n=4)$.

The effect of various concentrations of 2-chloroadenosine on the phosphorylation of Protein I in facial nucleus slices is shown in Figure 4. A double reciprocal plot of the data shown in Figure 4 was linear; the $V_{\max }$ for the 2chloroadenosine-induced stimulation of Protein I phosphorylation was $33.3 \%$ and the $K_{m}$ for this effect was 8.8 $\times 10^{-5} \mathrm{M}$.

The effect of $\mathrm{Ca}^{2+}$-free medium on 2-chloroadenosine stimulation of Protein I phosphorylation. 2-Chloroadenosine $\left(5 \times 10^{-4} \mathrm{M}\right)$ produced a $25.3 \pm 4.2 \%$ conversion of dephospho-Protein I to phospho-Protein I when incubated for $10 \mathrm{~min}$ with slices of facial nucleus in the presence of $1.5 \mathrm{~mm} \mathrm{Ca}^{2+}$ in the incubation medium and

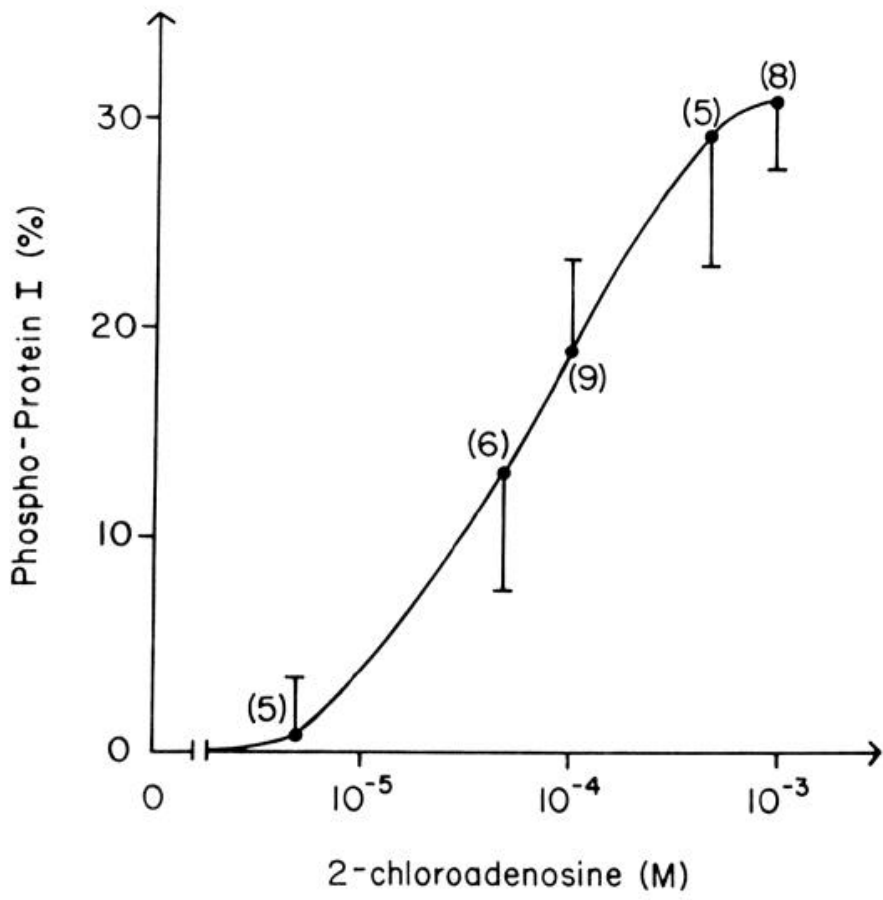

Figure 4. Effect of various concentrations of 2-chloroadenosine on the conversion of dephospho- to phospho-Protein I in slices of rat facial nucleus. All incubations were carried out in KRB containing $1.5 \mathrm{~mm} \mathrm{Ca}^{2+}$. For each concentration of 2 chloroadenosine, one of each pair of facial nuclei was incubated in the presence and one in the absence of this agent for $10 \mathrm{~min}$. Data show the means \pm SEM for the number of pairs of incubations given in parentheses.
Limited SAP Proteolysis of Protein I

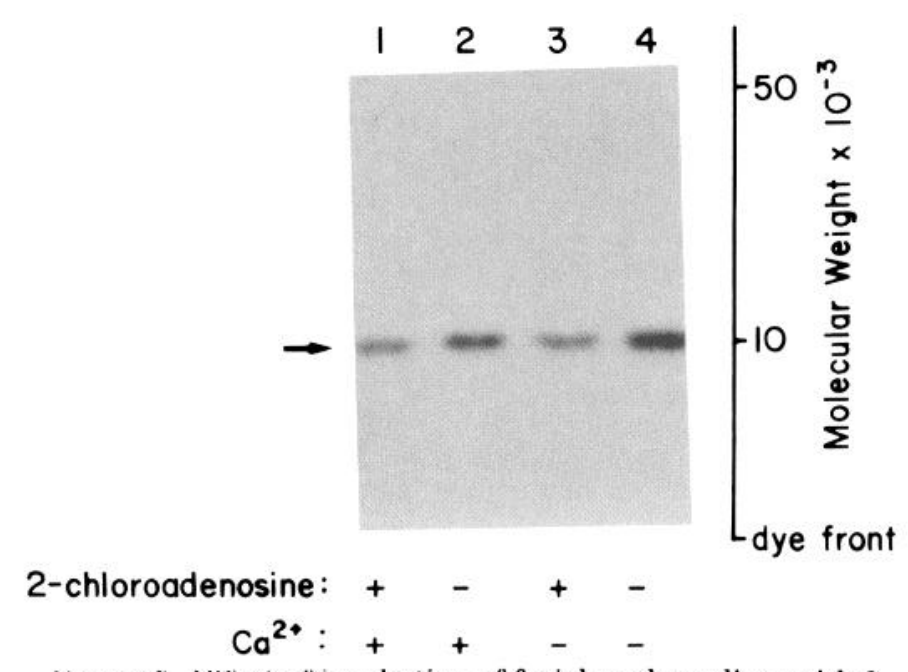

Figure 5. Etfect of incubation of facial nucleus slices with 2chloroadenosine $\left(10^{-3} \mathrm{M}\right)$ on the state of phosphorylation of the $M_{r}=10,000$ phosphorylated fragment of Protein I. Slices were incubated in KRB containing either $1.5 \mathrm{mM} \mathrm{Ca}^{2+}$ (lanes 1 and 2 ) or 0.3 mm EGTA (lanes 3 and 4). One of each pair of facial nuclei was incubated in the presence (lanes 1 and 3) and one in the absence (lanes 2 and 4) of 2-chloroadenosine. Further experimental details are provided in the legend to Figure 1. Stimulation of phosphorylation of Protein I due to 2-chloroadenosine in this experiment was $28.6 \%$ in the presence and $29.4 \%$ in the absence of $\mathrm{Ca}^{2+}$. The stimulation of phosphorylation of the $M_{r}=10,000$ phosphopeptide due to 2-chloroadenosine was $31.1 \%$ in the presence of $\mathrm{Ca}^{2+}$ (lane 1 versus 2 ) and $32.5 \%$ in the absence of $\mathrm{Ca}^{2+}$ (lane 3 versus 4 ).

a $26.8 \pm 4.5 \%$ conversion in the absence of $\mathrm{Ca}^{2+}(n=6)$. In the same series of experiments, the effect of $60 \mathrm{~mm} \mathrm{~K}^{+}$ was entirely blocked in the absence of $\mathrm{Ca}^{2+}$. In this series of experiments, the basal level of back phosphorylation of Protein $\mathrm{I}$ by $\left[\gamma^{3{ }^{32}} \mathrm{P}\right] \mathrm{ATP}$ was $9.1 \pm 1.2 \mathrm{pmol}$ of phosphate/mg of protein $(n=6)$ in the presence of $\mathrm{Ca}^{2+}$ and $14.9 \pm 0.9 \mathrm{pmol}$ of phosphate $/ \mathrm{mg}$ of protein $(n=6)$ in its absence. The effects on Protein I phosphorylation of 2chloroadenosine and of incubation of slices in $\mathrm{Ca}^{2+}$-free medium were also observed in the $M_{r}=10,000$ phosphorylated fragment produced by SAP digestion of Protein I (Fig. 5, lanes 1 to 4 ).

Inhibition of the effects of 2-chloroadenosine, ATP, and $\mathrm{K}^{+}$on Protein I phosphorylation by the adenosine antagonist, $2^{\prime}$-deoxyadenosine. As shown in Table II, $2^{\prime}$ deoxyadenosine $\left(10^{-3} \mathbf{M}\right)$ alone had a negligible effect on Protein I phosphorylation, but it inhibited the phosphorylation of Protein I due to $10^{-3} \mathrm{M} 2$-chloroadenosine by $67.1 \%$ and that due to $5 \times 10^{-4} \mathrm{M} 2$-chloroadenosine was inhibited almost completely $(90.5 \%)$. Similarly, $2^{\prime}$-deoxyadenosine inhibited the phosphorylation of Protein I due to $10^{-3} \mathrm{M}$ ATP by $43.9 \%$ and that due to $5 \times 10^{-4} \mathrm{M}$ ATP by $49.8 \%$.

The presence of $2^{\prime}$-deoxyadenosine $\left(10^{-3} \mathrm{M}\right)$ partially prevented the phosphorylation of Protein I seen upon incubation of facial nucleus slices with high $\mathrm{K}^{+}$for 10 min but not that seen after a 1-min incubation with high $\mathrm{K}^{+}$(Table II). 
TABLE II

Inhibition by the adenosine antagonist 2 -deoxyadenosine of Protein I phosphorylation due to 2-chloroadenosine, ATP, and $K^{+}$

The experimental member of each pair of facial nucleus slices was incubated with the indicated stimulatory agent for 1 or 10 min and, where indicated, with $2^{\prime}$-deoxyadenosine as well. The control member of each pair was incubated in the absence of any of these substances. $2^{\prime}$ Deoxyadenosine was added $10 \mathrm{~min}$ before the end of the incubation in the $\mathrm{K}^{+}$experiments and $12 \mathrm{~min}$ before the end of the incubation in all other cases. The percentage of conversion of dephospho-Protein I to phospho-Protein I was determined as described under "Materials and Methods." The values are the means \pm SEM for the numbers of determinations given in parentheses.

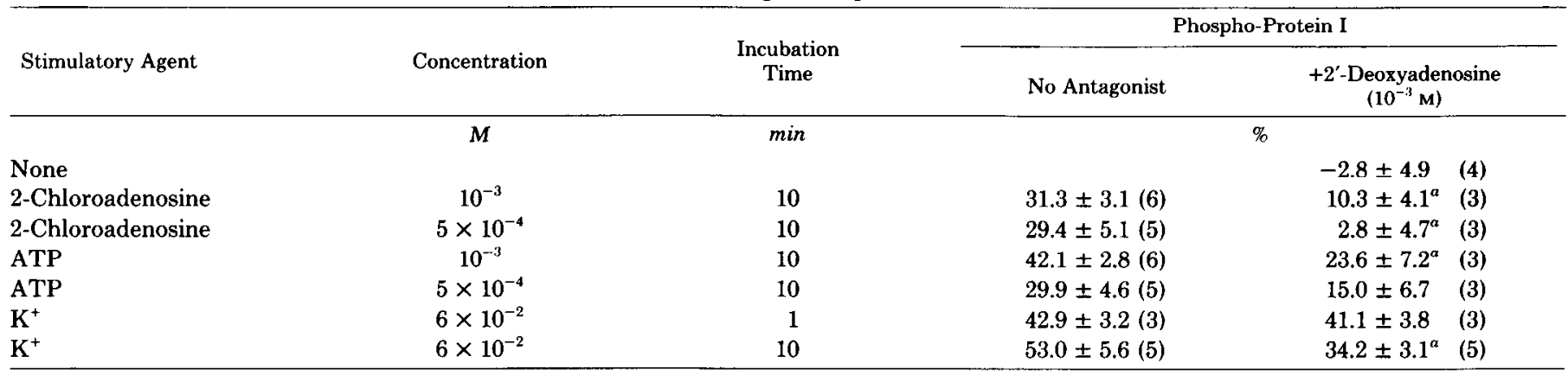

${ }^{a} p<0.05$, compared to absence of 2'-deoxyadenosine (Student's $t$ test).

\section{Effect of various lesions of the rat facial nucleus on the level of Protein I within this nucleus}

Intraventricular 5,7-dihydroxytryptamine (5,7-DHT) lesions. These experiments were performed in order to investigate the extent to which the serotonergic terminals in the facial nucleus might contribute to its content of Protein I. Protein I levels were determined in the facial nucleus by phosphorylation and by radioimmunoassay 7 days after intraventricular administration to adult rats of $200 \mu \mathrm{g}$ of 5,7-DHT or its vehicle. As a measure of the efficacy of intraventricularly administered 5,7-DHT in destroying 5-HT-containing fibers, the levels of 5-HT were determined fluorimetrically in the cerebral cortices of the same animals.

Left and right sides were analyzed separately, but no differences were observed, and the data were pooled. The administration of 5,7-DHT resulted in a $66 \%(p<0.01)$ drop in cortical 5-HT levels, but only a slight fall in the Protein I content of the facial nucleus, measured either by phosphorylation (Table III) or by radioimmunoassay (data not shown). These results were confirmed by immunohistochemical visualization of Protein I in the facial nucleus of control and 5,7-DHT-lesioned rats (A. C. Dolphin and P. De Camilli, unpublished results).

Kainic acid lesions of the facial nucleus. These experiments were performed in order to determine whether the cell bodies of the motoneurons might contribute to the Protein I content of the facial nucleus. Six days after the infusion of $0.1 \mu \mathrm{g}$ of kainic acid (in $0.5 \mu \mathrm{l}$ of vehicle) into the left facial nucleus of adult rats, Protein I levels in the left facial nucleus were $84.8 \pm 8.7 \%(n=7)$ of those in the right facial nucleus. The infusion of vehicle alone produced a similar change, the levels in the left facial nucleus being $84.1 \pm 2.6 \%(n=4)$ of those in the right facial nucleus. In all the kainic acid-lesioned rats, the position of the needle within the facial nucleus was identified by the ability of kainic acid to stimulate the left vibrissae within $30 \mathrm{sec}$ after the start of the 20 -min infusion and by observation of the needle track upon dissection of the tissue. Six days after lesioning, there was an observable loss of function of the left compared to the right vibrissae in five out of seven of the animals
TABLE III

Protein I levels in the facial nucleus and 5-HT levels in the cerebral cortex 7 days after intraventricular 5,7-dihydroxytryptamine lesions

The values are the means \pm SEM for the number of determinations shown in parentheses.

\begin{tabular}{lcc}
\hline & $\begin{array}{c}\text { Protein I Concentration } \\
\text { in Facial Nucleus: } \\
\text { Phosphate Incorporated } \\
\text { into Protein I }\end{array}$ & 5-HT in Cerebral Cortex \\
\hline Vehicle & pmol/mg protein & $n g / g m$ wet weight \\
$5,7-\mathrm{DHT}$ & $8.6 \pm 1.3(8)$ & $318.1 \pm 14.6(8)$ \\
\hline
\end{tabular}

${ }^{a} p<0.01$, when compared to vehicle-treated rats (Student's $t$ test).

injected with kainic acid, but not in the control animals. Histological examination of the facial nucleus was performed by cresyl violet staining of serial $50-\mu \mathrm{m}$ transverse sections after perfusion with $10 \%$ buffered formalin of two other kainic acid-lesioned rats. This revealed extensive loss of neuronal cell bodies in the region of the tip of the needle track, amounting to about $40 \%$ of the total in the sections examined (extending for about $600 \mu \mathrm{m}$ within the facial nucleus). These lesions of the facial nucleus with $0.1 \mu \mathrm{g}$ of kainic acid were thus by no means complete, resulting in an estimated 25 to $30 \%$ loss of facial motor neurons. However, it proved impossible to obtain a more complete lesion, because higher doses of kainic acid injected into this brainstem region were lethal.

\section{Discussion}

The great majority of Protein I appears to be localized in presynaptic nerve terminals (Bloom et al., 1979; Ueda et al., 1979; W. B. Huttner, P. De Camilli, S. E. Goelz, and $P$. Greengard, unpublished results). That this is the case for the facial motor nucleus is indicated both by immunohistochemical studies at the light microscopic level which suggest that motoneuron somata and dendrites contain little Protein I (A. C. Dolphin and P. De Camilli, unpublished observations) and by the results of the present study in which microinjections of kainic acid were made into the facial nucleus. When injected into 
the facial nucleus at a concentration that destroys neuronal cell bodies and interneurons in other brain regions (for review, see Nadler, 1979) and which, indecd, produced a substantial loss of facial motoneuron cell bodies, kainic acid did not cause any greater reduction in Protein I in this nucleus than did its vehicle alone. This is in contrast to the finding that kainic acid microinjections into the striatum caused a marked reduction in its Protein I content (Sieghart et al., 1978); however, the high concentration of interneurons in the striatum probably contributed largely to this effect. The absence of interneurons in the facial nucleus (Courville, 1965; McCall and Aghajanian, 1979a) is in line with the lack of effect of kainic acid on the Protein I level in this nucleus.

It follows that the stimulation of Protein I phosphorylation caused by 5-HT and adenosine in slices of rat facial nucleus occurs, at least in part, in neuronal terminals which contain Protein I. It would appear that cyclic AMP mediates the 5-HT-induced phosphorylation of Protein I, as the effect is potentiated by a low concentration of the phosphodiesterase inhibitor, IBMX (Dolphin and Greengard, 1981). The results suggest the existence of a class of 5-HT receptor linked to adenylate cyclase in the facial nucleus. For several reasons, it seems unlikely that these receptors are located exclusively on the 5-HT nerve terminals. 5-HT terminals account for only about $2 \%$ of the total terminals in the facial nucleus (Aghajanian and McCall, 1980), and in the present experiments, the level of Protein I in the facial nucleus was only slightly reduced after destruction of these terminals with 5,7-DHT, while the maximal effect of 5-HT was to convert about $30 \%$ of Protein I from the dephospho- to the phospho-form (Dolphin and Greengard, 1981). These results indicate that, while Protein I may be present in the 5-HT terminals, it is very probably also present in other terminals in the facial nucleus, a large portion of which comprises the terminals of the excitatory afferents onto the facial motoneurons. It is thus likely that there are presynaptic 5-HT receptors linked to adenylate cyclase on these terminals.

The postsynaptic 5-HT receptor on the facial motoneurons has been studied extensively by McCall and Aghajanian $(1979 a, b ; 1980)$ and by Vander Maelen and Aghajanian (1980). This receptor mediates the ability of 5-HT to facilitate the firing of the facial motoneurons induced by iontophoretically applied glutamate. The action of 5-HT on these receptors is mimicked by the serotonergic agonist, 5-MeO-DMT, and is blocked by classical peripheral 5-HT antagonists including metergoline, methysergide, and cyproheptadine.

In the present studies, the effect of 5-HT on Protein I phosphorylation was partially mimicked by $p$-chlorophenylethylamine, presumably through the release of endogenous 5-HT (Hwang and Van Woert, 1979). 5-MeODMT, a 5-HT receptor agonist with properties similar to $d$-lysergic acid diethylamide ( $d$-LSD) (Fuxe et al., 1972; de Montigny and Aghajanian, 1977), also slightly stimulated Protein I phosphorylation. 5-MeO-DMT appeared to act as a partial agonist at these 5-HT receptors, since it reduced the stimulation of Protein I phosphorylation caused by 5-HT itself. The results of previous studies suggest that it is a less potent agonist and, possibly, like $d$-LSD, a partial agonist of 5 -HT-sensitive adenylate cyclase in collicular homogenates from newborn rat (Enjalbert et al., 1978). The 5-HT antagonist, mianserin (Vargaftig et al., 1971; Nelson et al., 1978; Howlett and Nahorski, 1980), had an effect on Protein I phosphorylation which was similar to that of 5-MeO-DMT, although it inhibited 5-HT-stimulated Protein I phosphorylation to a greater extent. Another 5-HT antagonist, cyproheptadine, which is structurally related to mianserin (Vargaftig et al., 1971), also stimulated Protein I phosphorylation when incubated with slices of rat facial nucleus in the absence of serotonin. It has been observed previously that, whereas low concentrations of these and other 5HT antagonists inhibited 5-HT-sensitive adenylate cyclase, concentrations greater than about $10^{-5} \mathrm{M}$ stimulated adenylate cyclase activity in the same system (Enjalbert et al., 1978).

The inability of another classical 5-HT antagonist, metergoline (Fuxe et al., 1975, 1978), to inhibit 5-HTinduced phosphorylation of Protein I when incubated in vitro with facial nucleus slices suggests that this class of 5-HT receptor may be different from that investigated by McCall and Aghajanian (1979a, 1980) as, in their system, either iontophoretically applied or intravenous metergoline was a very potent antagonist of the effect of 5-HT on facial motoneuron firing. However, when metergoline was administered in vivo, the stimulation by 5 HT of Protein I phosphorylation was reduced by $35 \%$ in treated compared to control animals. This is in agreement with the finding that metergoline had very long lasting inhibitory effects in the facial nucleus (McCall and Aghajanian, 1980), despite its classification as a competitive inhibitor from 5-HT-sensitive adenylate cyclase (Enjalbert et al., 1978) and [ $\left.{ }^{3} \mathrm{H}\right]-5-\mathrm{HT}$ binding studies (Nelson et al., 1978).

The $\mathrm{Ca}^{2+}$ dependence of the 5-HT-stimulated phosphorylation of Protein I in facial nucleus slices may reflect a presynaptic mechanism such as that which has been put forward by Klein and Kandel (1978) and Shimahara and Tauc (1977) for certain Aplysia neurons. In these presynaptic terminals, 5 -HT is believed to stimulate a presynaptic adenylate cyclase, and the elevated intraterminal cyclic AMP levels increase the influx of $\mathrm{Ca}^{2+}$. In the present system, this $\mathrm{Ca}^{2+}$ influx as well as the raised cyclic AMP levels might contribute to Protein I phosphorylation. Another factor which could contribute to the $\mathrm{Ca}^{2+}$ dependence of 5-HT-stimulated Protein I phosphorylation is the substantial reduction in $\left[{ }^{3} \mathrm{H}\right]-5$ HT binding to cortical membranes which has been reported to occur in $\mathrm{Ca}^{2+}$-free media (Bennett and Snyder, 1976; Nelson et al., 1978).

The basal level of dephospho-Protein I, measured by "back phosphorylation" of extracted Protein I in control facial nucleus slices, was reproducibly about $40 \%$ greater after preincubation and incubation of slices in $\mathrm{Ca}^{2+}$-free medium than in medium containing $1.5 \mathrm{mM} \mathrm{Ca}^{2+}$ (cf., Fig. 5). Further experiments are in progress to clarify the effect of $\mathrm{Ca}^{2+}$ on Protein I phosphorylation in slices under basal conditions.

Although there is some evidence for the existence of distinct purinergic neurons in the peripheral nervous system, there is little evidence for their existence in the brain (for reviews, see Burnstock, 1975, 1977, 1978). Nevertheless, adenosine is ubiquitous in the central nervous 
system and is released into the medium upon depolarization of brain slices (Kakiuchi et al., 1969; Huang et al., 1973a; Mah and Daly, 1976). Moreover, adenosine is known to stimulate adenylate cyclase in neuronal cells in culture (Blume et al., 1973; Penit et al., 1976; Van Calker et al., 1979), in slices of cerebral cortex (Sattin and Rall, 1970; Huang et al., 1973b; Smellie et al., 1979), and in broken cell preparations of brain (Prémont et al., 1977, 1980). The physiological significance of adenosine in the nervous system is unknown although it has been found to inhibit the release of neurotransmitters from peripheral nerves and brain tissue (Vizi and Knoll, 1976; Clanachan et al., 1977; Harms et al., 1978; De Mey et al., 1979) and to inhibit spontaneous or electrically induced firing of neurons (Kuroda et al., 1976; Phillis and Edstrom, 1976; Reddington and Schubert, 1979) as well as to produce metabolic effects such as stimulation of glycogenolysis in brain slices (Wilkening and Makman, 1976).

From considerations similar to those put forward for the 5-HT receptors that mediate phosphorylation of Protein $I$ in the facial nucleus, it is likely that the adenosine receptors studied in the present investigation are also localized to a large extent on presynaptic terminals. In this study, three agents tested, ATP, adenosine, and 2chloroadenosine, were found to increase the phosphorylation of Protein I. All three agents have heen reported previously to raise cyclic AMP levels in brain slices (Sattin and Rall, 1970; Wilkening and Makman, 1975; Mah and Daly, 1976). The effect of 2-chloroadenosine on Protein I phosphorylation was not dependent on the presence of extracellular $\mathrm{Ca}^{2+}$ and is probably mediated by direct activation of adenylate cyclase.

It has been suggested that the effect of ATP is mediated through its metabolism by ecto-ATPases and $5^{\prime}$ nucleotidases to adenosine (Clark et al., 1974; Mah and Daly, 1976; Pons et al., 1980). The fact that two analogs of ATP, namely 2'-deoxy-ATP and AMP-PNP, which are not converted to adenosine (Mah and Daly, 1976; Phillis and Edstrom, 1976), did not stimulate phosphorylation of Protein I is consistent with this interpretation.

Several possible objections can be raised to the validity of results purporting to show the existence of membrane adenosine receptors associated with adenylate cyclase, and these apply equally well to the present system. Firstly, adenosine and its agonist analogs may increase the intracellular ATP pool and thereby increase cyclic AMP formation. In the present system, these effects might result in a generalized increase in protein kinase activity as well as a stimulation of cyclic AMP-dependent protein kinase. However, it has been shown that inhibition of adenosine uptake by dipyridamole increases the adenosine stimulation of adenylate cyclase (Clark et al., 1974; Van Calker et al., 1979) in neural tissue and potentiates the depressant effect of adenosine on cortical neurons in vivo (Phillis and Edstrom, 1976). In addition, 2chloroadenosine and other stable adenosine derivatives stimulate adenylate cyclase in brain slices as well as in cell-free systems, although they are not significantly converted to ATP derivatives (Sturgill et al., 1975; Wilkening and Makman, 1975; Daly, 1976).

Secondly, the stimulation of phosphorylation of Protein I caused by ATP might be attributable to dilution of the specific activity of the $\left[\gamma^{-32} \mathrm{P}\right] \mathrm{ATP}$ used in the final assay system. However, the decrease in ${ }^{32} \mathrm{P}$ incorporation into phosphoproteins in extracts from slices stimulated with ATP, compared to control slices, was specific for certain phosphoproteins, including Protein I, rather than being an overall effect. Moreover, the pattern of specificity for certain phosphoproteins was similar to that observed with 2-chloroadenosine. In addition, $0.1 \mu \mathrm{mol}$ of ATP added at the zinc acetate homogenate step, calculated to be the maximum amount which could have been carried over from the incubation into the extraction procedure, had no effect on subsequent Protein I phosphorylation in the extract.

The ability of the adenosine receptor antagonist, $2^{\prime}$ deoxyadenosine (Mah and Daly, 1976), to inhibit the effect of both 2-chloroadenosine and ATP on Protein I phosphorylation indicates that these two agonists are acting similarly on an extracellular adenosine receptor. That 2 -deoxyadenosine did not inhibit the effect of stimulation of slices for $1 \mathrm{~min}$ with $\mathrm{K}^{+}(60 \mathrm{mM})$ indicates that it is not acting intracellularly as an inhibitor of protein kinases, although it is a potent inhibitor of the purified enzyme in vitro (Miyamoto et al., 1969).

In the present study, in contrast to the results of sludies with slices of rat cerebral cortex (Forn and Greengard, 1978), the effect of $60 \mathrm{~mm} \mathrm{~K}^{+}$on Protein I phosphorylation was not attenuated after incubation for 10 min (Table II, compare $\mathrm{K}^{+} 1$ and $10 \mathrm{~min}$ ). However, concomitant incubation with $2^{\prime}$-deoxyadenosine significantly inhibited the stimulation of Protein I phosphorylation produced after a $10-\mathrm{min}$ incubation with $60 \mathrm{mM} \mathrm{K} \mathrm{K}^{+}$. This suggests that released adenosine contributed to the effect of $60 \mathrm{~mm} \mathrm{~K} \mathrm{~K}^{+}$on Protein I phosphorylation during the more prolonged incubation. In agreement with this finding, there is evidence that adenosine is responsible in part for the depolarization-evoked accumulation of cyclic AMP in slices of guinea pig cortex (Huang et al., 1973a; Mah and Daly, 1976; Pons et al., 1980).

Protein I appears to be associated primarily with synaptic vesicles (Bloom et al., 1979; Ueda et al., 1979; W. B. Huttner, P. De Camilli, S. E. Goelz, and P. Greengard, unpublished results), and its phosphorylation can be induced by agents such as elevated $\mathrm{K}^{+}$and veratridine which also cause release of neurotransmitters (Blaustein et al., 1972; De Belleroche and Bradford, 1972; Levy et al., 1973; Forn and Greengard, 1978; Huttner and Greengard, 1979). It has been postulated that the phosphorylation-dephosphorylation cycle of Protein I may be related to the mechanism of vesicular release of neurotransmitters (Greengard, 1980). This hypothesis is supported by the ability of agents which raise intracellular cyclic AMP levels to produce a phosphorylation of Protein I in intact neuronal tissue (Forn and Greengard, 1978), since cyclic AMP has been implicated as a modulator of the calcium-dependent release process in many systems (Breckenridge et al., 1967; Wooten et al., 1973; Miyamoto and Breckenridge, 1974; Skirboll et al., 1977; Klein and Kandel, 1978).

The present study indicates that two agents, 5-HT and adenosine, thought to play roles either as neurotransmitters or as neuromodulators in the nervous system (Burnstock, 1975; Fuxe, 1965; Reader, et al., 1979) affect the state of phosphorylation of Protein I in the facial nucleus by interaction with neuronal membrane receptors. From 
electrophysiological studies, it appears that a major effect of the 5-HT input to the facial nucleus is to facilitate motoneuron excitation by a direct action on motoneuron cell bodies (McCall and Aghajanian, 1979a; Vander Maelen and Aghajanian, 1980). In addition, from electron microscopic autoradiography utilizing $\left[{ }^{3} \mathrm{H}\right]-5-\mathrm{HT}$, the 5HT terminals in this nucleus were seen to form synapses only with motoneuron somata and dendrites (Aghajanian and McCall, 1980). However, both 5-HT and adenosine have been found to be involved in the presynaptic modulation of transmitter release in several systems (Dudel, 1965; Vizi and Knoll, 1976; Shimahara and Tauc, 1977; Harms et al., 1978; Klein and Kandel, 1978; De Mey et al., 1979), and the effect of these two agents on Protein I phosphorylation in the facial nucleus indicates that they may play a neuromodulatory role in the regulation of synaptic activity of neuronal terminals in the facial nucleus.

\section{References}

Aghajanian, G. K., and R. B. McCall (1980) Serotonergic synaptic input to facial motoneurons: Localization by electronmicroscopic autoradiography. Neuroscience, in press.

Beavo, J. A., P. J. Bechtel, and E. G. Krebs (1974) Preparation of homogeneous cyclic AMP-dependent protein kinase(s) and its subunits from rabbit skeletal muscle. Methods Enzymol. 38C: 299-309.

Bennett, J. P., Jr., and S. H. Snyder (1976) Serotonin and lysergic acid diethylamide binding in rat brain membranes: Relationship to postsynaptic serotonin receptors. Mol. Pharmacol. 12: 373-389.

Blaustein, M. P., E. M. Johnson, and P. Needleman (1972) Calcium-dependent norepinephrine release from presynaptic nerve endings in vitro. Proc. Natl. Acad. Sci. U. S. A. 69: 2237-2240.

Bloom, F. E. (1975) The role of cyclic nucleotides in central synaptic function. In Reviews of Physiology, Biochemistry and Pharmacology, pp. 1-103, Springer-Verlag, Berlin.

Bloom, F. E., T. Ueda, E. Battenberg, and P. Greengard (1979) Immunocytochemical localization in synapses of Protein I, an endogenous substrate for protein kinases in mammalian brain. Proc. Natl. Acad. Sci. U. S. A. 76: 5982-5986.

Blume, A. J., C. Dalton, and H. Sheppard (1973) Adenosinemediated elevation of cyclic $3^{\prime}: 5$ '-adenosine monophosphate concentrations in cultured mouse neuroblastoma cells. Proc. Natl. Acad. Sci. U. S. A. 70: 3099-3102.

Bockaert, J., J. Prémont, J. Glowinski, J. P. Tassin, and A.- M. Thierry (1977) Topographical distribution and characteristics of dopamine and $\beta$-adrenergic-sensitive adenylate cyclases in rat frontal cerebral cortex, striatum, and substantia nigra. In Advances in Biochemical Psychopharmacology, E. Costa and G. L. Gessa, eds., Vol. 16, pp. 29-37, Raven Press, New York.

Bradford, M. M. (1976) A rapid and sensitive method for the quantitation of microgram quantities of protein utilizing the principle of protein-dye binding. Anal. Biochem. 72: 248-254.

Breckenridge, B. McL., J. H. Burn, and F. M. Matschinsky (1967) Theophylline, epinephrine and neostigmine facilitation of neuromuscular potentiation. Proc. Natl. Acad. Sci. U. S. A. 57: 1893-1897.

Burnstock, G. (1975) Purinergic transmission. In Handbook of Psychopharmacology, L. L. Iversen and S. H. Snyder, eds., Vol. 5, pp. 131-194, Plenum Press, New York.

Burnstock, G. (1977) The purinergic nerve hypothesis. Ciba Found. Symp. 48: 295-314.

Burnstock, G. (1978) A basis for distinguishing two types of purinergic receptor. In Cell Membrane Receptors for Drugs and Hormones: A Multidisciplinary Approach, K. W. Straub and L. Bolis, eds., pp. 107-118, Raven Press, New York.

Clanachan, A. S., A. Johns, and D. M. Paton (1977) Presynaptic inhibitory actions of adenine nucleotides and adenosine on neurotransmission in the rat vas deferens. Neuroscience 2: $597-602$

Clark, R. B., R. Gross, Y.- F. Su, and J. P. Perkins (1974) Regulation of adenosine $3^{\prime}: 5^{\prime}$-monophosphate content in human astrocytoma cells by adenosine and the adenine nucleotides. J. Biol. Chem. 249: 5296-5303.

Cleveland, D. W., S. G. Fischer, M. W. Krischner, and U. K. Laemmli (1977) Peptide mapping by limited proteolysis in sodium dodecyl sulfate and analysis by gel electrophoresis. $J$. Biol. Chem. 252: 1102-1106.

Courville, J. (1965) The nucleus of the facial nerve: The relation between cellular groups and peripheral branches of the nerve. Brain Res. 1: 338-354.

Dahlström, A., and K. Fuxe (1965) Evidence for the existence of monoamine neurones in the central nervous system. II. Experimentally-induced changes in the intraneuronal amines of the bulbospinal neuron systems. Acta Physiol. Scand. 64: $1-36$.

Daly, J. W. (1976) The nature of receptors regulating the formation of cyclic AMP in brain tissue. Life Sci. 18: 13491358.

De Belleroche, J. S., and H. F. Bradford (1972) Metabolism of beds of mammalian cortical synaptosomes: Response to depolarizing influences. J. Neurochem. 19: 585-602.

De Camilli, P., T. Ueda, F. E. Bloom, E. Battenberg, and P. Greengard (1979) Widespread distribution of Protein I in the central and peripheral nervous system. Proc. Natl. Acad. Sci. U. S. A. 76: $5977-5981$.

De Camilli, P., R. Cameron, and P. Greengard (1980) Localization of Protein I by immunofluorescence in the adult and developing nervous system. J. Cell Biol., in press.

De Mey, J., G. Burnstock, and P. M. Vanhoutte (1979) Modulation of the evoked release of noradrenaline in canine saphenous vein via presynaptic receptors for adenosine but not ATP. Eur. J. Pharmacol. 55: 401-405.

de Montigny, C., and G. K. Aghajanian (1977) Preferential action of 5-methoxytryptamine and 5-methoxydimethyltryptamine on presynaptic serotonin receptors: A comparative iontophoretic study with LSD and serotonin. Neuropharmacology 16: 811-818.

Dolphin, A. C., and P. Greengard (1981) Serotonin stimulates the phosphorylation of Protein I, a synapse-specific protein, in the facial motor nucleus of rat brain. Nature, in press.

Dolphin, A. C., J. Adrien, M. Hamon, and J. Bockaert (1979) Identity of $\left[{ }^{3} \mathrm{H}\right]$ dihydroalprenolol binding sites and $\beta$-adrenergic receptors coupled with adenylate cyclase in the central nervous system. Pharmacological properties, distribution and adaptive responsiveness. Mol. Pharmacol. 15: 1-15.

Dudel, J. (1965) Facilitatory effects of 5-hydroxytryptamine on the crayfish neuromuscular junction. Naunyn-Schmiedbergs Arch. Exp. Pathol. Pharmakol. 249: 515-528.

Enjalbert, A., M. Hamon, S. Bourgoin, and J. Bockaert (1978) Postsynaptic serotonin-sensitive adenylate cyclase in the central nervous system. II. Comparison with dopamine and isoproterenol-sensitive adenylate cyclases in rat brain. Mol. Pharmacol. 14: 11-23.

Forn, J., and P. Greengard (1978) Depolarizing agents and cyclic nucleotides regulate the phosphorylation of specific neuronal proteins in rat cerebral cortex slices. Proc. Natl. Acad. Sci. U. S. A. 75: 5195-5199.

Fuxe, K. (1965) Evidence for the existence of monoamine neurons in the central nervous system. IV. Distribution of monoamine nerve terminals in the central nervous system. Acta Physiol. Scand. 64: 37-85.

Fuxe, K., B. Holmstedt, and G. Jonsson (1972) Effects of 5- 
methoxy- $N, N$-dimethyltryptamine on central monoamine neurons. Eur. J. Pharmacol. 19: 25-34.

Fuxe, K., L. Agnati, and B. Everitt (1975) Effects of methergoline on central monoamine neurons. Evidence for selective blockade of central 5-HT receptors. Neurosci. Lett. 1: 283290.

Fuxe, K., S.- O. Ogren, L. F. Agnati, and G. Jonsson (1978) Further evidence that methergoline is a central 5 -hydroxytryptamine receptor blocking agent. Neurosci. Lett. 9: 195200.

Greengard, P. (1979) Cyclic nucleotides, phosphorylated proteins and the neuronal system. Fed. Proc. 38: 2208-2217.

Greengard, P. (1980) Intracellular signals in the brain. Harvey Lect., in press.

Harms, H. H., G. Wardeh, and A. H. Mulder (1978) Adenosine modulates depolarization-induced release of $\left[{ }^{3} \mathrm{H}\right]$-noradrenaline from slices of rat brain neocortex. Eur. J. Pharmacol. 49: 305-308.

Hegstrand, L. R., P. D. Kanof, and P. Greengard (1976) Histamine-sensitive adenylate cyclase in mammalian brain. Nature 260: $163-165$.

Howlett, D. R., and S. R. Nahorski (1980) Quantitative assessment of heterogeneous ${ }^{3} \mathrm{H}$-spiperone binding to rat neostriatum and frontal cortex. Life Sci. 26: 511-517.

Huang, M., E. Gruenstein, and J. W. Daly (1973a) Depolarization-evoked accumulation of cyclic AMP in brain slices: Inhibition by exogenous adenosine deaminase. Biochim. Biophys. Acta 329: 147-151.

Huang, M., A. K. S. Ho, and J. W. Daly (1973b) Accumulation of adenosine cyclic $3^{\prime}, 5^{\prime}$-monophosphate in rat cerebral cortical slices. Mol. Pharmacol. 9: 711-717.

Huttner, W. B., and P. Greengard (1979) Multiple phosphorylation sites in Protein $I$ and their differential regulation by cyclic AMP and calcium. Proc. Natl. Acad. Sci. U. S. A. 76: 5402-5406.

Huttner, W. B., L. J. DeGennaro, and P. Greengard (1981) Differential phosphorylation of multiple sites in purified Protein I by cyclic AMP-dependent and calcium-dependent protein kinases. J. Biol. Chem. 256: 1482-1488.

Hwang, E. C., and M. H. Van Woert (1979) p-Chlorophenylethylamine-A unique serotonin agonist. Soc. Neurosci. Abstr. 5: 551.

Kakiuchi, S., and T. W. Rall (1968) The influence of chemical agents on the accumulation of adenosine $3^{\prime}, 5^{\prime}$-phosphate in slices of rabbit cerebellum. Mol. Pharmacol. 4: 367-378.

Kakiuchi, S., T. W. Rall, and H. McIlwain (1969) The effect of electrical stimulation upon the accumulation of adenosine $3^{\prime}, 5^{\prime}$-phosphate in isolated cerebral tissue. J. Neurochem. 16: 485-491.

Kebabian, J. W., and D. B. Calne (1979) Multiple receptors for dopamine. Nature 277: 93-96.

Kebabian, J. W., G. L. Petzold, and P. Greengard (1972) Dopamine-sensitive adenylate cyclase in caudate nucleus of rat brain, and its similarity to the "dopamine receptor." Proc. Natl. Acad. Sci. U. S. A. 69: 2145-2149.

Klein, M., and E. R. Kandel (1978) Presynaptic modulation of voltage-dependent $\mathrm{Ca}^{2+}$ current: Mechanism for behavioral sensitization in Aplysia californica. Proc. Natl. Acad. Sci. U. S. A. 75: 3512-3516.

Koe, C. K., and A. Weissman (1966) p-Chlorophenylalanine. A specific depletor of brain serotonin. J. Pharmacol. Exp. Ther. 154: 499-516.

Krebs, E. G., and J. A. Beavo (1979) Phosphorylation-dephosphorylation of enzymes. Annu. Rev. Biochem. 48: 923-959.

Krueger, B. K., J. Forn, and P. Greengard (1977) Depolarization-induced phosphorylation of specific proteins, mediated by calcium ion influx, in rat brain synaptosomes. J. Biol. Chem. 252: 2764-2773.

Kuo, J. F., and P. Greengard (1969) Cyclic nucleotide-depen- dent protein kinases. IV. Widespread occurrence of adenosine $3^{\prime}, 5^{\prime}$-monophosphate-dependent protein kinase in various tissues and phyla of the animal kingdom. Proc. Natl. Acad. Sci. U. S. A. 64: $1349-1355$.

Kuroda, Y., M. Saito, and K. Kobayashi (1976) Concomitant changes in cyclic AMP level and postsynaptic potentials of olfactory cortex slices induced by adenosine derivatives. Brain Res. 109: 196-201.

Levy, W. B., D. A. Redburn, and C. Cotman (1973) Stimuluscoupled secretion of $\gamma$-aminobutyric acid from rat brain synaptosomes. Science 181: 676-678.

Liu, A. Y. -C., and P. Greengard (1976) Regulation by steroid hormones of phosphorylation of a specific protein common to several target organs. Proc. Natl. Acad. Sci. U. S. A. 73: 568-572.

Lowry, O. H., N. J. Rosebrough, A. L. Farr, and R. J. Randall (1951) Protein measurement with the Folin phenol reagent. J. Biol. Chem. 193: 265-275.

Mah, H. D., and J. W. Daly (1976) Adenosine-dependent formation of cyclic AMP in brain slices. Pharmacol. Res. Commun. 8: 65-79.

McCall, R. B., and G. K. Aghajanian (1979a) Serotonergic facilitation of facial motoneuron excitation. Brain Res. 169: 11-27.

McCall, R. B., and G. K. Aghajanian (1979b) Denervation supersensitivity in the facial nucleus. Neuroscience 4: 15011510.

McCall, R. B., and G. K. Aghajanian (1980) Pharmacological characterization of serotonin receptors in the facial motor nucleus. Eur. J. Pharmacol. 65: 175-183.

Miyamoto, M. D., and B. McL. Breckenridge (1974) A cyclic adenosine monophosphate link in the catecholamine enhancement of transmitter release at the neuromuscular junction. J. Gen. Physiol. 63: 609-624.

Miyamoto, E., J. F. Kuo, and P. Greengard (1969) Cyclic nucleotide-dependent protein kinases. III. Purification and properties of adenosine $3^{\prime}, 5^{\prime}$-monophosphate-dependent protein kinase from bovine brain. J. Biol. Chem. 244: 6395-6402.

Nadler, J. V. (1979) Kainic acid: Neurophysiological and neurotoxic actions. Life Sci. 24: 2289-3000.

Nathanson, J. A. (1977) Cyclic nucleotides and nervous system function. Physiol. Rev. 57: 157-256.

Nelson, D. L., A. Herbert, S. Bourgoin, J. Glowinski, and M. Hamon (1978) Characteristics of central 5-HT receptors and their adaptive changes following intracerebral 5,7-dihydroxytryptamine administration in the rat. Mol. Pharmacol. 14: 983-995.

Nestler, E. J., and P. Greengard (1980) Dopamine and depolarizing agents regulate the state of phosphorylation of Protein I in the mammalian superior cervical sympathetic ganglion. Proc. Natl. Acad. Sci. U. S. A., in press.

Palkovits, M., and D. M. Jacobowitz (1974) Topographic atlas of catecholamine and acetylcholinesterase-containing neurons in the rat brain. II. Hindbrain (mesencephalon, rhombencephalon). J. Comp. Neurol. 157: 29-42.

Palkovits, M., M. Brownstein, and J. M. Saavedra (1974) Serotonin content of the brainstem nuclei in the rat. Brain Res. 80: 237-249.

Penit, J., J. Huot, and S. Jard (1976) Neuroblastoma cell adenylate cyclase: Direct activation by adenosine and prostaglandins. J. Neurochem. 26: 265-273.

Perkins, J., and M. Moore (1973) Characterization of the adrenergic receptors mediating a rise in cyclic $3^{\prime}, 5^{\prime}$-adenosine monophosphate in rat cerebral cortex. J. Pharmacol. Exp. Ther. 185: 371-378

Phillis, J. W., and J. P. Edstrom (1976) Effects of adenosine analogs on rat cerebral cortical neurons. Life Sci. 19: 10411054.

Pons, F., R. F. Bruns, and J. W. Daly (1980) Depolarization- 
evoked accumulation of cyclic AMP in brain slices: The requisite intermediate adenosine is not derived from hydrolysis of released ATP. J. Neurochem. 34: 1319-1323.

Prémont, J., M. Perez, and J. Bockaert (1977) Adenosine-sensitive adenylate cyclase in rat striatal homogenates and its relationship to dopamine and $\mathrm{Ca}^{21}$-sensitive adenylate cyclases. Mol. Pharmacol. 13: 662-670.

Prémont, J., M. Perez, G. Blanc, J.- P. Tassin, A.- M. Thierry, D. Hervé, and J. Bockaert (1980) Adenosine-sensitive adenylate cyclase in rat brain homogenates: Kinetic characteristics, specificity, topographical, subcellular and cellular distribution. Mol. Pharmacol. 16: 790-804.

Reader, T. A., A. Ferron, L. Descarries, and H. H. Jasper (1979) Modulatory role for biogenic amines in the cerebral cortex. Microiontophoretic studies. Brain Res. 160: 217-229.

Reddington, M., and P. Schubert (1979) Parallel investigations of the effects of adenosine on evoked potentials and cyclic AMP accumulation in hippocampus slices of the rat. Neurosci. Lett. 14: 37-42.

Sattin, A., and T. W. Rall (1970) The effects of adenosine and adenine nucleotides on the cyclic adenosine $3^{\prime}, 5^{\prime}$-phosphate content of guinea pig cerebral cortex slices. Mol. Pharmacol. 6: 12-23.

Shimahara, T., and L. Tauc (1977) Cyclic AMP induced by serotonin modulates the activity of an identified synapse in Aplysia by facilitating the active permeability to calcium. Brain Res. 127: 168-172.

Sieghart, W., J. Forn, R. Schwarcz, J. T. Coyle, and P. Greengard (1978) Neuronal localization of specific brain phosphoproteins. Brain Res. 156: 345-350.

Skirboll, L., L. Baizer, and K. L. Dretchen (1977) Evidence for a cyclic nucleotide-mediated calcium flux in motor nerve terminals. Nature 268: 352-354.

Smellie, F. W., C. W. Davis, J. W. Daly, and J. N. Wells (1979) Alkylxanthines: Inhibition of adenosine-elicited accumulation of cyclic AMP in brain slices and of brain phosphodiesterase activity. Life Sci 24: 475-482.

Sturgill, T. W., B. K. Schrier, and A. G. Gilman (1975) Stimulation of cyclic AMP accumulation by 2-chloroadenosine, lack of incorporation of nucleoside into cyclic nucleotides. J. Cyclic Nucleotide Res. 1: 21-30.
Ueda, T., and P. Greengard (1977) Adenosine 3':5'-monophosphate-regulated phosphoprotein system of neuronal membranes. I. Solubilization, purification and some properties of an endogenous phosphoprotein. J. Biol. Chem. 252: 51555163.

Ueda, T., H. Maeno, and P. Greengard (1973) Regulation of endogenous phosphorylation of specific proteins in synaptic membrane fractions from rat brain by adenosine $3^{\prime}: 5^{\prime}$-monophosphate. J. Biol. Chem. 248: 8295-8305.

Ueda, T., P. Greengard, K. Berzins, R. S. Cohen, F. Blomberg, D. J. Grab, and P. Siekevitz (1979) Subcellular distribution in cerebral cortex of two proteins phosphorylated by a cAMPdependent protein kinase. J. Cell Biol, 83: 308-319.

Van Calker, D., M. Müller, and B. Hamprecht (1979) Adenosine regulates via two different types of receptors the accumulalion of cyclic AMP in cultured brain cells. J. Neurochem. 33: 999-1005.

Vander Maelen, C. P., and G. K. Aghajanian (1980) Intracellular studies showing modulation of facial motoneurone excitability by serotonin. Nature 287: 346-348.

Vargaftig, B. B., J. L. Coignet, C. J. de Vos, H. Grisjsen, and I. L. Bonta (1971) Mianserin hydrochloride: Peripheral and central effects in relation to antagonism against 5-hydroxytryptamine and tryptamine. Eur. J. Pharmacol. 16: 336-346.

Vizi, E. S., and J. Knoll (1976) The inhibitory effect of adenosine and related nucleotides on the release of acetylcholine. Neuroscience $1: 391-398$.

Walsh, D. A., J. P. Perkins, and E. G. Krebs (1968) An adenosine $3^{\prime}, 5^{\prime}$-monophosphate-dependent protein kinase from rabbit skeletal muscle. J. Biol. Chem. 243: 3763-3765.

Wilkening, D., and M. H. Makman (1975) 2-Chloroadenosinedependent elevation of adenosine $3^{\prime}, 5^{\prime}$-cyclic monophosphate levels in rat caudate nucleus slices. Brain Res. 92: 522-528.

Wilkening, D., and M. H. Makman (1976) Stimulation of glycogenolysis in rat caudate nucleus slices by 1-isopropyl norepinephrine, dibutyryl cyclic AMP and 2-chloroadennsine. J. Neurochem. 26: 923-928.

Wooten, G. F., N. B. Thoa, I. J. Kopin, and J. Axelrod (1973) Enhanced release of dopamine- $\beta$-hydroxylase from sympathetic nerves by dibutyryl cyclic adenosine $3^{\prime}, 5^{\prime}$-monophosphate and theophylline. Mol. Pharmacol. 9: 178-183. 